\title{
Symbolism of the Shadows in Son of Man by Roa Bastos
}

\author{
Patricia G. Montenegro \\ Cheyney University of Pennsylvania, Cheyney, USA
}

\begin{abstract}
In his novel Son of Man, Augusto Roa Bastos uses images and symbols of shadows to represent the ramifications of the Paraguayan Dr. José Rodríguez de Francia’s dictatorship. Rodriguez de Francia’s legacy, which begins during the postcolonial years and extends well into the 20th century, resonates in the novel in socio-political structures and characters' ideologies and behaviors. It allows for plantation owners to enslave workers and their families; it confines and oppresses people through unfounded legends and myths; and among other things, it creates a false idea of purpose and patriotism in the Chaco War (1932-1935), which in the end lets down the soldiers. To counteract these deleterious social conditions, Roa Bastos creates surreal characters, such as a fantastic helper who aids plantation workers to escape dehumanizing situations. Roa Bastos also narrates how the people in Itapé, a small town, make an idol of a Christ statue carved by one of their own. However, when the two Goiburú brothers replace the statue by crucifying their sister's rapist, the people's myth is destroyed. Likewise, Roa Bastos avails himself of Christian and Catholic concepts and symbols to transpose them into a humanistic ideology so as to convey hope to his people through a new perspective. In this way, a new Annunciation takes place when the son of a raped woman is born. In the end, Roa Bastos lets the course of these warped transpositions take their logical denouement: In the absence of a purpose beyond an earthly existence, death becomes the narrator's option.
\end{abstract}

An idol is as ephemeral as his creator

Keywords: Paraguay, Dr. Rodríguez de Francia, dictatorship, surrealism, myth, Chaco War, Annunciation, born again, halo

\section{Introduction}

The images of shadows throughout the entire novel Son of Man by Augusto Roa Bastos are abundant and different in nature. They appear in various contexts and with distinct meanings. Such is their pervading recurrence that they become a leitmotif, one that sets a gloomy tone for most of the settings. They encompass characters, historical figures, places, oppressive socio-political structures, and perplexing or absurd events. The concept of the shadow is implied in the obscure nature of legends and myths. It is the essential end product of a repetitive historical dictatorial process in Paraguay, as seen by Roa Bastos, whose perspective is so coherent that his use of the concept of the shadow, in spite of its diverse manifestations, coincides with, and at times surpasses the definition in the Spanish Royal Academy's dictionary:

Patricia G. Montenegro, Ph.D., Associate Professor, Department of English, Languages and Communication Arts, Cheyney University of Pennsylvania.

Correspondence concerning this article should be addressed to P.O. Box 139 Cheyney, PA 19319. E-mail: pgertrudis@earthlink.net,pmontenegro@cheyney.edu. 
Obscurity, a more or less complete lack of light. An obscure projection, which a body casts on a space opposite to that from which the light comes. An obscure image. A ghost or a faint and fantastic apparition of an absent or dead person's image. Obscurity (lack of light and knowledge). ${ }^{1}$

The most crucial image of a shadow in Son of Man represents the absolute power of Paraguay's first dictator, Dr. Gaspar Rodríguez de Francia, who ruled from 1814 to 1840. His actions (cruel toward some people, yet compassionate toward others) made him controversial. ${ }^{2}$ Rodríguez de Francia’s referential presence at the very beginning of the text, parallels his determining historic appearance at the beginning of Paraguay’s independence in 1811. Thus, Roa Bastos lays a foundation for the reader to understand that an underlying cause of Paraguay's dictatorial pattern is found in Rodríguez de Francia's own dictatorship, as he casts a long shadow over his country. Roa Bastos suggests this through a character of the old Macario, whose father worked for Rodríguez de Francia, also known as el Supremo. When Macario recounts his stories to the children of Itapé at the beginning of the novel, the image of el Supremo is both impressive and terrifying: "El Supremo stood out vividly for us against a background of night skies, keeping watch over the country which he ruled with an iron will and a power as great as that of destiny itself.” (p. 19). The use of the term "destiny” to refer to Rodríguez de Francia's power, suggests the inexorable bearing he had on Paraguay's history long after his death. Furthermore, in the original Spanish version of Son of Man the narrator also describes him as a shadow: "we too had nightmares about the Big Chief, but we could not bring ourselves to hate him [his shadow]” (p. 19). ${ }^{3}$ That is, he is shown as an entity, a mere intangible presence, which, in spite of its indefinite and intangible nature, contributes to the social construct of an undefeatable political structure that would linger in the Paraguayan mindset for years to come.

As Macario shows the children el Supremo's shoe buckle, which he has kept for years, the collective narrator conveys the omnipresence of a ruler whom, as a romantic force of nature-_lightning”- no one had been able to overcome: "We looked thoughtfully at the buckle [a meteorite fallen in a desert]. ${ }^{4}$ We seemed to see a patent-leather shoe, a pair of white stockings, a thin figure [shadow] in a frock coat, tall as a tree which has withstood the lightning.” (p. 22). The obscure nature of this figure-shadow representing Rodríguez de

\footnotetext{
1 “Sombra.” Def. Diccionario de la lengua española, 22a ed. (España: Espasa Calpe) 2001. Except for the novel, Son of Man, all other translations in this essay are mine.

2 The novel's factual narrative of Rodríguez de Francia's conflicting policies are but a repetition of historical accounts: Other policies were more controversial. Although Francia advocated power in the hands of the people, he suppressed free speech. People who dissented from Francia within the country were often tortured and disappeared without trial. Anyone suspected of anti-Francian sentiments would be sent to a detention camp where he or she would be shackled in dungeons and denied health care.

Online. Facts On File Inc. http://www.fofweb.com/activelink2.asp?ItemID=WE53\&iPin=WHV089\&SingleRecord=True (accessed July 29, 2014).

Likewise, we read in Son of Man: Macario must have been born a few years after the Perpetual Dictatorship was established. His son Pilar, an emancipated slave, was El Supremo'svalet, and bore his name. Many of the slaves whom Francia set free-while at the same time enslaving innumerable families in his prisons-had taken his name, which seemed to symbolize the somber colour of the age (Emphasis mine) Roa Bastos, Augusto. Son of Man. Trans. Rachel Caffyn. (New York: Monthly Review Press, 1988$) 18$.

3 This paper is based on Rachel Caffyn's translation of the Spanish novel Hijo de hombre to the English Son of Man. However, when essential words from the original text are missing or interpreted in ways that hinder my discussion, a literal translation of the omitted words will be given in brackets next to Caffyn's translation to adhere to textual analysis to support my thesis statement in this paper.

${ }^{4}$ It is to consider the Spanish text, "Un aereolito caído en un desierto,” which translates literally as "a meteorite fallen in a desert,” since Roa Bastos implicitly equates Rodríguez de Francia's glistening buckle to a meteorite because both emit some type of light. Furthermore, a meteorite actually struck Paraguay in El Chaco Boreal during el Supremo's first years of government. The extravagant dictator had his armies locate and bring the 100,000 kilograms (220,462lbs) rock to his palace. The outlandish project lasted around five years and over one hundred men died. In the end, the walls of the dictator's palace had to be torn down to bring the meteorite inside. "El meteorito del Dr. Francia" en www.revisionistas.com.ar.
} 
Francia is an omen of the forthcoming heinous events wreaked by the structure that oppresses and, in many instances, destroys the lives of many characters in the ensuing chapters. Hence, Rodríguez de Francia is dictatorship, portrayed as an ominous recurrent shadow behind an authoritarian structure, which dehumanizes or exploits characters throughout the novel, represents a seemingly invincible historical determinism in Paraguay.

One sees the all powerful dictatorial structure laid by el Supremo's arbitrary rule reproduced in the Paraguayan yerba mate plantation of Takurú-Pukú. Located in the jungles of Alto Paraná, Tukurú-Pukú has been turned into a prison-like plantation. Naïve peasants are lured to work here by industrial agents who promise to pay them hefty salaries and give them money in advance. The workers enthusiastically accept the offers only to see themselves exploited later to the point of being unable to live for no other purpose than the economic interests of the state and private companies:

Men who worked under the threat of the whip every day of the year, and only rested on Good Friday, as though they, too, were taken down from their cross on that day, as Christ was. Only for those obscure, barefoot Christs there was no glorious resurrection; they died unredeemed and forgotten. And that was the state of things not only in the mate plantations run by the government, but in privately-owned estates as well. (p. 81)

Roa Bastos explicitly establishes a historical connection between these infernal plantations and President Cirilo Antonio Rivarola's government regulations to denounce his role in the oppression within the yerba plantation. ${ }^{5}$ To this end, he quotes a promulgated law that thoroughly favors and protects industry "for the prosperity and advancement of the cultivators of yerba mate and other branches of the national economy" (p. 81). Furthermore, Roa Bastos finds it necessary to quote another section of the law that enslaves the farmworker to the detriment of his own family life because, once he is legally bound, the members of the families are bound as well.

If a laborer abandons his work without the written consent of his master or foreman, he shall, if his master so wishes, be brought back by force, and the expenses incurred in bringing him back and any other expenses arising from his action, shall be charged to his account. (p. 81)

In this manner, Roa Bastos creates a plantation that operates under the same legal framework, authenticating his fiction with a social equivalent to denounce the dire exploitation and unbearable working conditions during President Rivarola’s regime (1870-1871) and long thereafter. ${ }^{6}$

On the yerba plantation, the chief of police of Takurú Pukú and the estate, Juan Cruz Chaparro, is twice described through his obscure and hateful ways, first, through the image "the manager's loathsome shadow" (p. 84) and second, through the names farmworkers use to refer to him because of his cruelty: "Juan Kurusú, they

\footnotetext{
${ }^{5}$ Antonio Rivarola was the provisional President in Paraguay 1870-1871. Although the official histories of Paraguay portray Rivarola as a praiseworthy president for abolishing slavery, he legally promoted enserfment as per the laws quoted by Roa Bastos. www.portalguarani.com/2124_cirilo_antonio_rivarola...

${ }^{6}$ Here, Roa Bastos seems to observe Georgi Plekhanov's recommendation for a critic and even revert the critic's model: "to translate from the language of art into the language of sociology," "which is the concept of social equivalent.” In other words, Roa Bastos, provides and even incorporates the actual historical legal framework into his creation of plantations. For the concept of “social equivalent” see Robert H. Stacy, Russian Literary Criticism: A Short History. New York: Syracuse University Press, 1974. 187. The importance of the term "social equivalent," albeit reverted, is definitely crucial inasmuch as Article 3, which is quoted by Roa Bastos is also quoted by Rafael Barrett in his study El dolor paraguayo. Furthermore, Barrett furnishes information about the annihilating conditions of the plantations: "almost all of the peons who have worked in the Alto Paraná from 1890 to 1900 have died. Out of three hundred men who were taken from Villarrica in 1900 for the yerbales in Tormenta in Brasil, only twenty came back.” as quoted by Lee Kyeong Min, "El poder de resistencia de la cultura popular dentro del Estado, en Hijo de hombre de Roa Bastos.” http://www.ucm.es/info/especulo/numero29/roabastos.html.
} 
called him behind his back, or just Kurusú, because that is what he was-the shadow of the cross on which the laborers hung. And Chaparro's whip was as swift and deadly as the sting of the 'cross' snake” (p. 84). In both descriptions, the image of Chaparro as a "shadow" fits quite well the pattern established with el Supremo. Chaparro is an authoritarian figure who abuses his power, as did Rodríguez de Francia, causing excruciating suffering comparable to that of the crucifixion. The narrator gives Chaparro the surname Cruz [Cross], which is revered in Christian tradition. The narrator also makes a play on words when characters refer to Juan Chaparro as "Kurusú", the Guarani word for "cross". Moreover, Chaparro is the "shadow of the cross", as well as the "cross snake". Behind Cruz, stands not only el Supremo, a chief of police, or a religious institution, but the entire concept of the Christian Cross, which alludes to Western Civilization. ${ }^{7}$ However, this cross no longer brings good tidings, hope, joy, life, salvation, light, but rather darkness, damnation, death, sadness, and despair. Therefore, the image of the Cross together with other images of it in Son of Man alters its Christian meaning into a symbol of the exact opposite.

Beyond the plantation, the dictatorial structure penetrates the inner being of humans as well, transforming them into non-persons. No one escapes the Takurú-Pukú plantation, or so the legend goes in the surrounding region. The exception to this mind set is Casiano Jara, his wife Nati and their newborn boy. Between death in the plantation and death as a consequence of their escaping the plantation, Casiano and Nati choose the latter. The love for their baby and the hope of a future for him provide them with enough energy to risk fleeing the plantation. Such are the exploitation and the subhuman living conditions in which Casiano and his wife live that the narrator renders their suffering obvious through the creation of arbitrary surrealistic images. ${ }^{8}$ When the couple is escaping the plantation, the narrator shows how their dignity has but disappeared to give way to a dark waste: "They go out, one behind the other, the man with the baby in his arms, and dragging the reluctant mother. [Their shadows] Crouching down, they cautiously make a long detour and then disappear into the monte" (p. 100). ${ }^{9}$ Chapter four, unsurprisingly, is titled "Exodus” echoing the biblical episode when Moses leads the Israelites out of oppressive Egypt. The extraordinary and miraculous aspect of Casiano, his wife and

\footnotetext{
${ }^{7}$ Although, referring not explicitly to the Cross, but to one of its adherents, the apostle St. Thomas who, according to the Jesuits, had appeared in Paraguay, Mercedes R. Robles states: "by recalling the St. Thomas/Thome (Tomé) myth so ingrained in Paraguayan lore, Roa Bastos attempts not so much to recover the fable for the fable's sake, but rather, on the one hand, to underline its continued presence in contemporary times under a different guise and, secondly, by doing so, to demystify alien redeemers.” Robles concludes: “There is a need, and the narrative makes an eloquent statement to that effect, to create (to recover!) for Paraguay and Latin America their own myths.”“'Syncretism in Roa Bastos’ Hijo de hombre. Romance notes, 35:2 (1994) 200, 202-203.

${ }^{8}$ The images of Casiano, his wife and child are surreal in that they arbitrarily change to shadows, shakint the complacent the reading to create an awareness of such an unbelievable reality that one is, by suspense, moved to read more in order to learn the whereabouts of the characters. Due to the blending of realistic and fantastic elements, the reader might be motivated by these surrealistic images to inquire into the socio-economic reality behind them. André Breton explains the importance of using arbitrary images thus: "the countless kinds of Surrealist images would require a classification which I do not intend to make today ... . what I basically want to mention is their common virtue. For me, their greatest virtue, I must confess, is the one that is arbitrary to the highest degree, the one that takes the longest time to translate into practical language, either because it contains an immense amount of seeming contradiction or because one of its terms is strangely concealed; or because, presenting itself as something sensational, it seems to end weakly (because it suddenly closes the angle of its compass), or because it derives from itself a ridiculous formal justification, or because it is of a hallucinatory kind, or because it very naturally gives to the abstract the mask of the concrete, or the opposite, or because it implies the negation of some elementary physical property, or because it provokes laughter.” Manifestos of Surrealism.Trans. Richard Seaver and Helen R. Lane. Ann Arbor: U Michigan, 1969. 38.

9 Here again, the translator omitted the metaphor on the original text. There is a reason why the narrator describes Casiano and his wife as shadows; they have become so after the grueling, grinding work and living conditions in the plantation and become nonhumans. Their portrayal as shadows is so important that the narrator repeats it during the couple's ordeal in the flight: "and these two figures (shadows) fleeting with their backs to the rising sun, splashing through the red streams left by the rain” (101).
} 
their child's escape through the dangers of the marshes, with their miasma, insects, and quicksand is accomplished by their own efforts. This is a human accomplishment, while the Israelites flee from the Pharaoh's bondage through God's miraculous intervention. It's a divine undertaking, but Casiano's goal is earthly. As he says to Nati: “We're fighting to get a little land! Some land of our own!” (p. 110). The Israelites goal is first to reach the Promised Land, which was pledged to Abraham. But more important, in Christian theology, it points out the path to eternal life: "Theologically, the Promised Land is a type of heaven for which believers long (Heb 4)." ${ }^{10}$ Heaven is a place where happiness will be achieved.

Two more incidents occur during Casiano's escape with his family, rendering the narration surreal. In the first incident, their fleeing course does not fit the ordinary sequence of actions as known by the guards when they have chased other escapees in the past. The narrator arbitrarily changes the circumstances, the regular course of events, and the nearly instituted legend that "no one escapes Takurú Pukú" to break the hopelessness of people who, like Casiano and his family, were trapped in a nightmarish plantation and in their mindset. Roa Bastos writes, "The guards were bewildered. This was the opposite of what they had expected, an inexplicable deviation from the usual course of a man-hunt [sic]... there was no sign of the ghostly figures they were seeking” (p. 105). As puzzled as the guards are with respect to the unfolding events, the reader is taken further to the last episode of this chapter in a fantastic ride in which Casiano and his wife encounter an old man, an apparition riding in an old cart, who plays the role of a helper as in a fantastic tale. This character miraculously appears from nowhere when the insurmountable obstacles of exhaustion seem to stop Casiano and his family and bring their hopes to an end. The helper's role is simply to assist them in their quest for freedom and their own land. The narrator's characterization of the old man, as though a mythical figure on a mythical journey, is purposefully surreal:

The old man did not look as if he had moved at all... But the old man did not seem to need sleep nor food nor rest. Neither did he speak. Nati did not hear his voice again at all during the journey... So in the end the old man seemed to her like a figure in a dream. (p. 112)

However, he utters no wise instructing words, but rather serves as a support, as a guide, fitting the description of helpers in other works of literature, as Dáithí Ó hÓgáin states in his article "Magic Helper”: “The role played by magic helpers is a favorite building block in many fantastic oral stories." ${ }^{11}$ After living in subhuman conditions on the plantation, without dignity, this is exactly what Casiano and his wife need: another person who, through his actions, is telling them that they are worth being rescued so that they may recover their humanity. Thus, the narrator no longer refers to them as "shadows".

The chances of finding someone to rescue the family from their ordeal are small, but through the helper's presence and actions one sees surrealism at its best or what has been known arguably as magical realism in Latin American literary criticism. Roa Bastos, through the arbitrary creation of a ghost-like helper and through the creation of chimera-like circumstances for Casiano, and Nati and their infant provides hope for the oppressed, the underdog, and the exploited workers. The couple and their baby, Cristobal, brake the pattern of

${ }^{10}$ Scott Hahn, Gen. Ed. Catholic Bible Dictionary . New York: Double Day, 2009. 733.

11 Dáithí Ó hÓgáin, "Magic Helper” The Greenwood Encyclopedia of Folktales and Fairy Tales, Donald Haase, ed. 3 vols. Connecticut: Greenwood Press, 2008. 596. Strangely enough, the definition of "helper” as understood by A. J. Greimas within his actantial model, fits well, if not, better, the role of the old man within the axis of power since Casiano's fate evidently has to do with the state's ruthless power to maintain the plantation: "the helper assists in achieving the desired junction between the subject and object; the opponent hinders the same.”Louis Hébert. “The actantial Model.” Theoretical Semiotics on the Web. All things have become signs in the water's reflection, 13 Aug. 2014. http://www.signosemio.com/greimas/actantial-model.asp (8. 13. 14). 
oppressive and destructive factors and are back in Sapukai.

Still more surreal is the train car left from the bomb that exploded to stop the peasants' uprising in which Casiano had participated two years earlier. His insurrection caused him and Nati to flee Sapukai for Takurú-Pukú. Unfounded accounts and superstitions created a legend around the miraculously preserved train car that Casiano, Nati and Cristóbal make their home upon their return to Sapukai and push for indefinite time into the woods. Roa Bastos calls it "a journey that would last for years, accompanied by his wife and child, three tiny human ants undertaking to convey this mass of wood and metal over the thirsty, cracked plain” (p. 126). The narrator emphasizes their Herculean task by identifying them as "ants" to contrast their miniscule size, as he relates the legend of the father, the mother, and their son moving the immense weight of the train car. We know now that this myth fulfills a social role as much as the extraordinary escape and the old man helper to generate hope among the people of Sapukai who had witnessed the suppression of the peasants' rebellion. ${ }^{12}$

As though history were repeating itself, Cristóbal Jara, now an adult, is sought by Sapukai soldiers just as they sought his father twenty years earlier. Cristóbal also joins a group of revolutionaries. However, one of their leaders, the narrator, Miguel Vera, inadvertently reveals the guerrilla fighters while he is drunk, and persecution ensues at once.

The revolutionaries are on the move. Cristóbal is hiding among the tombs in María Regalada's cemetery. As the soldiers search for the fugitive, they shoot a goat covered with a bag, thinking it is Cristóbal. Meanwhile, María distracts the soldiers from finding Cristóbal, informing them that the goat belongs to her. The captain, having interrogated María, commands his soldiers to carry the goat into her house.

While María and her son are preparing the goat together, the image of shadows serves as a catalyst that reveals the fear of Alejo, María's son. Having witnessed the soldiers' brutality, as he extracts the bullets one by one from the dead goat, Alejo succumbs to a fear of the ominous presence, an imposing power of the soldiers, which lingers over him. Basto writes, "María Regalada was dealing skillfully with the pieces of meat. The boy's eyes turned towards her, seeking closer contact with her; he felt oppressed and uneasy because of the silence and darkness [shadows]" (p. 153). This darkness or the shadows in the context of an oppressive presence is associated with an overwhelming, invincible authoritarianism of Rodríguez de Francia, who dominates the history in Paraguay and the storyline in two of Roa Bastos novels: I the Supreme and Son of Man. However, in Son of Man, Rodríguez de Francia is not the central character, although the dictatorial, inescapable socio-political structure he laid for Paraguay's future is suggested through the recurrent presence of shadows reminiscent of his own ominous shadow in the first pages of Son of Man. ${ }^{13}$ Thus, two patterns are repeated, the first when Cristobal becomes a rebel just as did his father years earlier; both suffer the same fate of persecution by the state's armed forces. The second repetition pertains to Rodríguez de Francia's shadow's extending or

\footnotetext{
12 Sapukai is the stage of two revolts. The first one, in which Casiano Jara is a leader, takes place in 1912. It fails because the telegraphist denounced it and the government forces brutally crushed it. In the second rebellion, Cristobal is one of the chief rebels. The relation between rebellions and myth has been analyzed by Adriana Valdés and Ignacio Rodríguez in "Hijo de hombre: Myth as a social force.” Taller de letras, 30.1 (2002): 75-95. "The characters in Son of Man also navigate compelled by an infinitely old fate, but not compelled by divine powers, but now, rather by earthly powers of indestructible human roots.” (p. 120) Further on, Valdés and Rodríguez conclude that "the myth in Son of Man, is rebellious, insurgent and the novel has for Paraguay and America an obvious significance of a call to action.” (p. 150).

13 With respect to Yo, el Supremo, Teresa Méndez Faith comments that "the dictator and the dictatorship as concrete beings and archetypes, which are repeated throughout Paraguay's history, pervade the text.” However, noticing a repetition of a similar kind in Son of Man, Méndez Faith identifies it as "a significant recurrence of 'jail-like spaces': closed spaces, suffocating and oppressive places, limited and limiting environments.” "Dictadura y 'espacios-cárceles': Doble reflejo de una misma realidad en Hijo de hombre y Yo el Supremo.” Cuadernos hispanoamericanos July-Aug. 493-494 (1991): 240.
} 
expanding in space and time into every organization from his political dictatorship (1814-1840) onward. ${ }^{14}$

Unlike the above episodes, in which the shadows represent a dictatorial invincible presence, there appears an altogether different type of darkness for the people of Sapukai, though it is no less oppressive. The shadow in these passages has to do with the unknown, with legends or superstitions, and how these dimensions of the social fabric affect the people of Sapukai. When a foreigner appears as if he were one of them, enjoying the same rights, his presence triggers the usual comments and his actions exert a noteworthy influence over the townspeople: "But up till that moment they had no more information about him. Nothing to go on but a name they could hardly pronounce, and the empty husk [shadow] of a man devoured by fate. The rest, the suspicions and rumors, were no more than dust blown in their eyes” (p. 51).

None of the townspeople knows the foreigner's exact origin. He is surrounded by a sense of mystery based on the lack of precise information. There is only conjecture about his diet and the distinct style of his ranch house, all of which is fuel for legends and myths. As the narrator so admits, the foreigner's otherness perplexes Sapukai's inhabitants through his own different cultural values, which are so alien to them. Even his name, Alexis Dubrovsky, is not Spanish sounding. His mystification, in part, comes from his having founded the leper colony, his daring generosity, and his medical skills, as when he sees María Regalada, the gravedigger's daughter, writhing in pain at the cemetery. He picks her up and takes her to her father's house, where he successfully performs surgery on her. As a consequence,

More and more people began to come to his round hut. From distant farms and neighboring villages they came, the sick and the paralyzed, on foot, on horseback and in carts. The lepers came too. The Doctor treated them all, quietly, patiently, making no differences between rich and poor, and refusing payment from the poorest. (p. 55)

Some of the mystery surrounding the doctor dissipates as he is a source of good health for many. However, discrepancy based on assumptions emerges almost as soon as his popularity spreads. Because of the Doctor's magnanimity and his hermit-like lifestyle, the priest virtually canonizes him. But the priest's praise is swiftly deflated by shrewd observers who have seen more of the doctor's activities or have been around long enough so as to disbelieve naive statements such as those of the priest:

"You may say what you like," said the priest that night during a pause in their card-game. "That man has renounced the world and all its works...”

“All except caña!"15 Interrupted the protector of illicit distillers "Like the hermits of old," concluded the priest, rather put out...

As you know better than us, Father (said the judge). Sooner or later our true nature will come out. We'll see how long that one can hold out...” (pp. 51-52)

\footnotetext{
${ }^{14}$ It is well known by people acquainted with the history of Paraguay that after Rodríguez de Francia's death several dictators ruled the country. Roa Bastos lived as an exile in Argentina and Spain for 40 years. The last Paraguayan dictator, Alfredo Stroessner, who ruled for thirty-five years, kept Roa Bastos in exile. Stroessner seems to have used some of Rodríguez de Francia’s practices. Remarkably, one of these was calling himself "El Excelentísimo,” (His Excellency) just as Rodríguez de Francia called himself "El Supremo.” Nonetheless, Stroessner's totalitarian, authoritarian rule, and despotism, by far, exceeded Rodríguez de Francia’s. Adam Berstein, “Alfredo Stroessner; Paraguayan Dictator,” The Washington Post 17 Aug. 2006. http://www.washingtonpost.com.

One should consider if the initial postcolonial superstructure, that is, Rodríguez de Francia's dictatorial regime was not a greater determining socio-political factor in the history of Paraguay than its infrastructure because it created a social fabric so easy to be reproduced. Consequently, Roa Bastos felt the need to expose these false dictatorial pillars upon which the Paraguayan socio-political fabric rested for nearly three centuries.

${ }^{15}$ Latin American cane liquor. <http://es.thefreedictionary.com/caña>.
} 
Eventually, the judge's words evince a dark side in the doctor, who for this precise reason, is a multi-dimensional character. He becomes more mysterious over time, as unexpected changes surprise the people of Sapukai and the reader. Having cured María, the doctor refuses any payment from her father. Nevertheless, feeling obligated, he repays the doctor by giving him a religious statute dating back to the times when the Jesuits settled in Paraguay and created the reductions (1585-1750). This statue, as well as others like it, is filled with gold and silver coins. The contents capture the doctor's attention and soul, so much so that Maria Regalada contemplates his metamorphosis from a kind, magnanimous, generous and helpful physician into a greedy and indifferent physician who has become as callous as the object of his new loves, gold and silver:

The Doctor was kneeling on the floor. A stream of gold and silver coins was running through his fingers, gleaming in the last light of the day and forming a little heap at his feet. His face was contorted. His blue eyes were troubled, almost despairing, as they had been when he could not save her father and on other occasions when he had been defeated by death. (p. 58)

Not surprisingly, the Doctor is depicted as though he were worshiping. One may judge he is falling into idolatry by his position, although he is kneeling not before God, but rather before precious metals. The narrator provides us only with his unfortunate end, "he went on like that for a few months, drunk, half-crazy and more silent than ever" (p. 59). A final judgment on Dubrovsky is cast when he "had then disappeared, leaving behind him these traces of his frightening but harmless madness. [leaving his beneficent shadow as a replacement and his monstrous madness]" (p. 155). One may speculate regarding the many reasons that led the Doctor to this unexpected transformation without finding satisfactory answers. Yet one thing is clear: The Doctor, with all his virtues, praiseworthy qualities, and ascetic lifestyle is not rooted in God, but in himself. In this vulnerable position he becomes a victim of his avarice and drunkenness. His is another shadow featuring mercy for the needy and the sick but is deranged because of his insatiable passions, replicating again the image of the compassionate but ruthless Rodríguez de Francia.

Through his practice, the doctor comes in contact with the hero Casiano. Few people in Sapukai recognize Casiano after his return from the ordeal at the yerba plantation at Takurú-Pukú. Casiano is overcome by malaria, and, worse still, the narrator describes him as a "lunatic" (p. 55). Dubrovsky cures the first ailment, but nothing is said about his deranged mind. Now the narrator undermines the highly cherished myth of the train car, underlining its harmful effects. He shows the correlation between misfortune and superstition to be a detrimental popular belief in which people have been ensnared:

His was the coach which was later seen traveling mysteriously through the countryside on wheels of fire.

But, of course, that was only another of the many legends which gained credence among a people whom misfortune had made a prey to superstition. (p. 55)

Here Roa Bastos uses the image of a shadow to reveal the dark side of rumors and suspicion surrounding the doctor and the train car. Then, he sets a correlation between the obscure side of shadows and the darkness of legends, myths and superstitions to identify them as a cultural destructive practice that only renders people vulnerable as they become prey to the imaginary. Nevertheless, one must consider the narrator's perspective about myths or legends. When Miguel Vera approaches the historic train car abandoned in the middle of the wilderness, his appraisal contains this time a positive insight of the solidarity behind the legend: 
And in that wild, lonely country, robbers, vagabonds, pariahs and fugitives of all kinds, even the lepers from the Russian doctor's colony, must have helped the man, the woman and the child to move the coach forward, so that they might, in return, share for a while this home which advanced over the plain without direction, without definite destination, but surrounding itself with a victorious, intrepid, wild, unreal atmosphere of security, courage and mystery, so that all those who encountered it were drawn into the conspiracy to keep it secret. (p. 121)

His own understanding of the train car is but one more conjecture. Roa Bastos, who uses historic aspects and figures of the Paraguayan reality such as the plantations, Rodríguez de Francia, and the Chaco War (1932-1935), looks for a reliable historical account of some of these events. Given the absence of information or the distorted versions in Paraguay's official history, Roa Bastos takes it upon himself to tell the other history, or "the story" to give a fuller picture of the untold history. He claims in an interview that the official history "has no value whatsoever". ${ }^{16}$

Precisely to uncover the unknown aspects of the Chaco War or the War of the Thirst, which deeply harmed Paraguay, Roa Bastos narrates the dark side of the battlefields. The images of shadows are dramatized and grow to surreal proportions bordering on the grotesque toward the end of this war. ${ }^{17}$ Their meaning stems from the number of people affected by the slaughter that takes place, as in any war, and by the harrowing effects on which the narrator capitalizes. One of these effects is the psychological burden of the massive annihilation. The narrator finds it imperative to create the surrealistic, arbitrary image par excellence first because the events of the war lend themselves to do so. Second, because the more shocking and absurd the image the more the attention and perhaps reaction it will receive. Roa Bastos writes, "it is possible now to see dimly, through the restless, ever-present dust, the shapes of sheds, of large collections of men and material, striped with blue-black shadows" (p. 177). ${ }^{18}$ In this manner, war, an unbearable human activity in which soldiers and civilians are caught without alternatives, is part of the dictator's ruthless side of his structural shadow. Furthermore, in this war, the soldiers ironically realize they are fighting for the very ones who exploit them - the heartless landowners in their own country (referred to as "on this side"), and the foreign companies (referred to as "on the other side"). Roa Bastos writes:

but not only for the title-deeds and shares of the property-owners on this side. We're going to fight and die too for those of the petroleum undertakings on the other side... The ones on this side and the ones on the other side! Standard Oil, Casado and company! (p. 172)

\footnotetext{
${ }^{16}$ His entire statement reads as follows: "What in Latin America we call history, that is, the history of the official historians, has no value whatsoever. On the contrary, it is precisely this false reality which we who write fiction feel obliged to contradict in every possible way. The testimony of power is ordinarily given by means of a false vision of lived history.” Roa Bastos, "An Interview with Augusto Roa Bastos,” ed. Javier M. González, trans. Peggy Boyers Skidmore College, Salmagundi 72 Fall (1986) 22-30 <http://www.jstor.org/stable/40547859>.

17 "Chaco War, (1932-35), costly conflict between Bolivia and Paraguay. Hostile incidents began as early as 1928 over the Chaco Boreal, a wilderness region of about 100,000 square miles (259,000 square km) north of the Pilcomayo River and west of the Paraguay River that forms part of the Gran Chaco. The conflict stemmed from the outcome of the War of the Pacific (1879-84), in which Chile defeated Bolivia and annexed that country's entire coastal region. Thereafter, Bolivia attempted to break out of its landlocked situation through the Río de La Plata system to the Atlantic coast; athwart that route lay the Gran Chaco, which the Bolivians thought had large oil reserves.” http://www.britannica.com/EBchecked topic/104130/Chaco-War.

${ }^{18}$ Roa Bastos tells that he witnessed the Chaco War firsthand: "I volunteered to fight that war when I was only fourteen. Because of my age they did no permit me to go to the front, but instead gave me auxiliary sorts of assignments which on occasion made me long for the front. The rear guard is always worse than the front in a war. That's where the most terrible misdeeds of war occur in their crudest from. One of my jobs was to watch the Bolivian prisoners, another was to keep track of the deaths. This is the sort of disagreeable activity I engaged in from day to day. To me confronting death directly at the front seemed preferable.” pp. 22-23 $<$ http://www.jstor.org/stable/40547859>.
} 
The Chaco War's sobriquet, The War of the Thirst, due to the waterless and barren region of the Chaco, ${ }^{19}$ adds another dimension to the gruesome scenes. In addition to the atrocities to which soldiers are usually subjected in any war, regional conditions in The War of the Thirst are intolerable, due to the shortage or lack of water. Hence, the narrator prefers to use a realistic style only to the point where reality itself allows him to do so. To be truthful and show a ghastly reality, he resorts to raw descriptions that, notwithstanding, must turn into surreal ones:

There is something uncanny about this handful of invisible defenders, defending with fiendish obduracy in their wooded stronghold. It is like fighting against phantoms endowed with a strength which comes from pain, a morbid, sinister strength which has passed all the normal limits of consumption, of annihilation, of desperation. (p. 183; emphasis mine)

After the crescendo, which culminates in "desperation," the narrator's subtle, but persistent pessimistic perspective is already surfacing, but will be bluntly dejected in the end.

Every war leaves scars and the human psyche undergoes transformations that may manifest themselves in several disorders. The War of the Thirst drove soldiers-Bolivians and Paraguayans alike-to the brink of madness. Beside the regular anxiety that any warfare produces, the prolonged shortage of water for several days makes soldiers loose their minds, even when the water had arrived: "Whole platoons, mad with thirst, desert the firing-line and fall on the water-trucks or on the valiant water-coolies” (p. 180). Together with dehydration, the corollary of subhuman war experiences and conditions cause the soldiers to metamorphose into specters. The narrator makes the reader notice the metamorphosis by using terms analogous to the Royal Spanish Academy's definition of "shadow" at the beginning of this essay: "ghost or faint and fantastic apparition." From his privileged observation post, the narrator comments: "I enjoy a comprehensive view of the dusty amphitheatre with its emaciated personages, almost stark naked and with their bones stiking [sic]out...Old looking men... they look like the ghosts of actors who are too drunk to remember their way home after the performance" (pp. 184-185).

Thus, the concept of shadows extends into the absurd grotesque reality of wars and its outcome of madness.

In this warfare scenario, the ironic title for chapter eight, "Special Mission", expands the meaning of shadows even further, reaching now a metaphysical dimension. This time it is not a historic figure, the whip of the plantation's foreman, an almost tangible fear of the menacing soldier's presence, or the doctor's madness, or even the war atrocities. It is a matter of an obstinate conviction for the sole sake of continuing for the illusion of gaining freedom. But freedom from what? The protagonist of this chapter, truck driver Cristóbal, is destined to fail his mission: no transcendence will warrant his sacrifice. The narrator refers to it as "a suicide mission” (p. 125). The sergeant explains the assignments, "Water and medical supplies have to be taken to a battalion cut off on the other side of the Boquerón... Whoever goes must be prepared not to come back. It's more or less certain that he won't even get there” (p. 192). Maybe this relentless certainty that once more confirms his fellow soldiers' misfortune in a mission with narrow chances of success arouses Cristobal's wishful thinking that he will somehow bring about a change. In an earlier episode, Cristóbal outsmarts the soldiers, and now, in the absence of personnel, he is ironically recruited as one of them to fight for his country at the outbreak of the Chaco War.

The old train car images, the episode, and the myth all resurface toward the end of "Special Mission". As a

${ }^{19}$ For a complete description of the Chaco, see “The Gran Chaco” by Fernando Riveros in <www.fao.org/ag/.../Granchaco.htm>. 
child, Cristóbal helps push the train car with the help of "robbers, vagabonds, pariahs and fugitives" (p. 121), which has become a legend. Now, Cristóbal must drive a water truck to the other side of Boquerón with little or no chances of success. At the end of confrontations, deprivations, troubles, hurdles and shelling, nearing the objective but gravely wounded, Cristóbal refuses to give up. As tenacious as his father when he escaped the Takurú-Pukú plantation, Cristóbal’s stubornness keeps him going. Roa Bastos writes:

The only thing that mattered was to go on, always at all costs, through the wood through the desert, through the merciless heat of the sun and the head of this dead friend, through this terrible country where life and death were indissolubly joined. That was his destiny. And what other destiny could there be for a man like Cristóbal Jara except to pursue the obsession which enslaved him along a narrow forest trail or over the limitless plain field filled with the savage smell of freedom. (p. 231; emphasis mine)

Both Casiano and Cristóbal are driven by an ideal of freedom. Cristóbal's mission is plagued from the beginning by failure due to the imposibility of the task, but, most important, by the very principles and conditions underpinning it. Reduced by the ideological outlook that the human potential suffices, Cristobal's mission is limited likewise by its own finite nature, letting him go only as far as his own strength enables him. As Cristóbal says, "what men cannot do, no one can do, he had said himself” (p. 231). This belief in Cristobal's mouth poses for Humberto Robles "a God-man relationship that the entire novel tends to deny."20

Indeed, once God has been displaced from center stage, something or someone else must take His place since an absolute void cannot subsist. As a supernatural absolute being, God would have to be replaced by an equivalent. Here surrealism is useful, because it provides a large array of seemingly fitting marvelous, magical, fantastic and unreal mythical events, such as a statue, human beings attempting to substitute for God's supernatural attributes. Within this anthropocentric milieu, in which the God-man relationship is conspicuous by its absence, it is not surprising that some Christian symbols have been transposed from their biblical spiritual meanings to earthly meanings. The biblical terminology, figures, and facts as interpreted from a Christian perspective in Son of Man are devoid of their spiritual meaning and replaced by Roa Bastos' humanistic ideology. ${ }^{21}$

The first such figure is a statue of Christ, which is created by Itapé's musician and carpenter, Gaspar Mora, after he contracts leprosy and leaves the town to live in the wilderness. Like Jesus, Gaspar is a carpenter, an indisputable benefactor who would share his money with the poor and even defray the farmers' debts. Such gestures had earned him the people's affection. For this reason, the Itapeños consider Gaspar's sculpture a saint's bequest, made by a man to represent men. However, when the Itapeños bring the sculpture inside the church, the priest refuses to keep it, as neither Gaspar had been canonized nor had the sculpture been blessed officially by the Catholic Church.

A strong superstition, or as the priest calls it, idolatry, already had begun growing roots among the Itapeños about Gaspar’s Christ. Their imagination, guided by Macario’s stories, takes flight as they describe the statue: "Its wooden mouth is speaking... It is saying things we must listen to... Listen! ...We cannot

\footnotetext{
20 “El círculo y la cruz in Hijo de hombre.” Nueva Narrativa Hispanoamericana 4 (1974) 194.

21 "Roa Bastos position with respect to the Indians' cause is clear. In Son of Man as well as in several of his short stories collection, El trueno entre las hojas, his determined solidarity with the oppressed and dispossed stands out... 'He felt that they were his only siblings and that he was united with them through the kinshhip of hope. Additionally, Roa Basto knew that holiness is possible only in the midst of misfortune and that the true temple of Christ is the martyr's heart.'” "Ensayo de interpretación de Hijo de hombre a través de su simbolismo cristiano y social,” Urte Lehnerdt in Homenaje a Augusto Roa Bastos; variaciones interpretativas en torno a su obra. Ed. Helmy F. Giacoman. New York: Las Américas, 1973. 176.
} 
understand God... but a man we can understand! (p. 35). Ascribing attributes or powers to a statue is magical thinking that triggers the birth of a myth. In a reversal of the Christian ideology by which the Itapeños suppose that God is beyond human intellectual reach, they depart from His revelation but not without Him. They retain some of the old Christian discourse while they adapt it to their own views. When they put words in the mouth of a statue that represents God laden with religious meaning, they use the power of Christian symbolism in an attempt to empower their pagan figure, which is a mere idol. ${ }^{22}$ The moment this misrepresentation has taken place, it verifies how a "myth is a type of speech" not chosen by history, but rather by story or better still, by the narrator (Barthes, p. 218). The myth constructed by Itapeños about the newly fabricated Christ "has in fact a double function: it points out and it notifies, it makes us understand something, and it imposes it on us" (Barthes, p. 226). ${ }^{23}$ The fabricated Christ statue points to a man-made god and imposes its implied message on us that humans are the new god.

In the same vein, the narrator's discourse borrows from the Genesis: “God created man in his image, in the divine image He created him” (1:27) to describe the Itapeños' understanding of Gaspar's creation of a statue of the crucified Christ. He "had made it in his own image. If a soul can take a physical shape, then this was the soul of Gaspar Mora” (p. 32). Therein lies the idea that every created work bears the imprint of its creator, which is self-explainatory. The problem, however, stems from an obvious intertextuality whereby the referent has been accorded a meaning by Christian tradition by divine revelation that Christ is not only the fruition of the Old Testament's Son of Man, but the Son of God Himself. What then does the Itapeños' reasoning mean as they conclude that the statue "was the soul of Gaspar Mora"? Since Jesus Christ is God, if any man can create his own sculpture of God and give it a new persona, everyone can have one’s own god in his or her own image. Not surprisingly, when the narrator recounts the Itapeños' rituals surrounding the Christ image, he notices how their interpretation of Christ's role is at variance with the Christian tradition. Every year, the Itapeños would bring down the image from the cross and parade it throughout the town. They regarded the Christ

as a victim they wanted to avenge and not as a God who had died willingly for men... a Redeemer as ragged as themselves who, like them, had been constantly mocked and ridiculed and persecuted, ever since the world began. Such a belief was, in itself, a reversal of normal faith, a permanent incitement to revolt. (p. 17)

In effect, this earthly outlook would stir the people to rise up in arms. This is logical from a wordly perspective, but is also a miscontrued interpretation of Christ's mission—a spiritual redemption from this world for a better, everlasting one, the Kingdom of God. The Itapeños' mythical perspective with "a permanent incitement to revolt”, and Rodríguez de Francia's dictatorial rule are found in the first chapter. Both constitute the powerful socio-political bedrocks of the characters' lives.

The words "Being born from above" (John 3.7), from the spirit, as Christ explains to Nicodemus, are redefined in Roa Bastos' novel and reduced to a mere human endeavor during Cristóbal's mission to drive the water truck to the soldiers dying of thirst in the War of the Thirst. En route to his destination, Cristóbal comes upon the prostitute Saluí, who is now regenerated by her love for him. She becomes an altogether different person. Sargent Silvestre Aquino, cognizant of Saluí's transformation and tenacity in the fighting, recognizes: "I thought this was just a whim of yours... But a whim like this is more than life itself... You're beign born

\footnotetext{
${ }^{22}$ Although the statue is neither silver or gold, but rather wooden, the basis behind the biblical words about idols can be applied in the same way: "their idols are silver and gold, / the work of human hands./ They have mouths but do not speak,/ . . Their makers shall be like them, all who trust in them.” Ps. 115. New American Bible. New York: Catholic Book Publishing Co. 1992. 680.

${ }^{23}$ Mythologies, “Part II: Myth Today,” trans. Annette Laver, 1st ed. New York: 2012.
} 
again, Saluí!” (p. 214). Neither is Cristóbal’s mission consistent with the Christian purpose of eternal salvation, nor is Saluí born spiritually as Jesus explains to Nicodemus: “Amen, amen, I say to you, no one can see the kingdom of God without being born from above” (John 3.3). Here, Roa Bastos is misrepresenting the concept of spiritual birth by transposing it from the godly realm to the secular sphere. As the spiritual and the secular are diametrically opposed, Roa Bastos creates an unbridgeable abyss between the two concepts: Saluí is doomed to die; Jesus is eternal.

In this same chapter, "Special Mission”, other Christian symbols are used with opposite significance as they are decontextualized and distorted for mundane reasons. A halo, which has long been identified as a symbol of holiness in the Roman Catholic tradition, now surrounds Saluís head, glorifying her. This twist has been fabricated within a humanistic ideology, which ironically borrowed meaning from its opposite, a God-based creed of Christianity, from which it is drawn. The narrator uses an oxymoron to describe Saluí's holiness: "She looked wild and terrible with her halo of dust [dirt]" (p. 233). A "halo", by definition, is light. On the contrary, "dust" or "dirt", as it reads on the Spanish original text of Son of Man, contradicts the whole idea of holiness in the Roman Catholic tradition. In its stead it proclaims an earthly, mortal standpoint.

Another religious symbol concerns Alejo Dubrovsky, the son of María Regalada and the Russian physician, who rapes her in a moment of rage before he leaves Sapukai. The narrator places Alejo on a supernatural level by availing himself of the term "annunciation”, which has Christian connotations, so as to subvert the very foundations of the ideology it underpins:

There was something holy [concerning annunciation] about this child, shut away in the lonely, inaccessible region of sleep, where past and future mingle. The fruit of rape, he was yet a proof of the innocence, the incorruptible purity of the human race, because in him time began again from the beginning. (p. 157)

Expressions such as "annunciation", "inaccessible region" and "in him time began again from the beginning", echo the Christian event of "the announcement made to Mary by the angel Gabriel that she was 'full of grace' and would become the Mother of the Messiah” (Hahn, p. 49). In Son of Man, in an earthly context, these expressions aim at producing a brand new Messiah, the human race, because of its "incorruptible purity". A new religious but mythical era is inaugurated through the statement "in him time began again from the beginning”, as though discourse could replace history, but which history? Paraguay's? The world's? Given their mythical nature, the words may refer to any history. Likewise, Alejo, who is the fruit of rape, breaks the analogy with Jesus, who was conceived by the Holy Spirit. Instead, there is what literary critics have identified as a cultural duality in Paraguay, where the Guaraní traditions coexist with Roman Catholicism. ${ }^{24}$ The two epigraphs preceding the whole narrative are the best case in point. One of the quotations is from the Book of Ezekiel, and the other, comes from the Hymn of the Dead of the Guaraní People. ${ }^{25}$ One of the biblical quotes reads: "and I will set my face against that man, and will make him a sign and a proverb, and I will cut him off from the midst of my people” (p. 14). This admonition is given in the context of idolatry to men who practice it. Is Roa Bastos using God's words to warn ruthless Paraguayan dictators of a punishment? What about the

\footnotetext{
${ }^{24}$ Paraguayan dualism of the Guaraní and Christian cultures is discussed in-depth by María Verónica Serra, "Bilingüismo y dualidad en Hijo de hombre de Augusto Roa Bastos” in Espéculo: Revista de Estudios Literarios Mar.-June: 32 (2006). [no pagination].

${ }^{25}$ For Rosa Audubert, confusion and uncertainty are part of the "mythical” dimension within the Bible and Son of Man's interxtuality. "El estigma de la cruz en Hijo de hombre de Augusto Roa Bastos” in Espéculo: Revista de Estudios Literarios, July-Oct. 21 (2002) [no pagination].
} 
people's idolatry, which falls more appropriately within Ezekiel's prophecy? The answer lies on the quote from the Hymn of the Dead: "My voice shall be heard again among the dead... And my word shall once more be made flesh... When this age is over and a new age begins” (p. 14). By paralleling the Guaraní quotes in which the word shall be made flesh and the Christian concept of the Word of God made flesh at the beginning of his novel, Roa Bastos assigns equal value to both. In the end, this ideological hybridization that is neither Christian nor Guaraní becomes another source of ambiguity and thus of textual obscurity. It’s one more shadow.

Gaspar's carved statue of Christ does not last. During the Chaco War, Itapé's jefe político [political chief], Melitón Isasi, abuses his power and uses two women as objects of his sexual pleasure. First the soldier Crisanto Villalba's wife, Juana Rosa, and second, the Goiburú brothers' sister, Felicita, whom he cajoles into the relationship with a few gifts and later is found dead. Upon their return from the Chaco War, the Goiburu brothers castrate Isasi and crucify him on the cross Gaspar's statue had occupied:

But the Goiburú twins wanted to show that it was possible that even this Christ, who had hung there for a quarter of a century in the fresh air... that even he should one day appear transformed into a jefe político, in great-coat, boots and gun-holster, and with a flabby face and bloodshot eyes over which the shadow of the vultures were already wheeling. (p. 247)

This time, as a romantic element of nature, the vultures cast their shadow over Isasi's cadaver, not any more as a black, dark omen of tragic events to come. They are the quintessential symbol of poetic justice that is meted out to Isasi, in a turn of destiny, by which the shadows cast by political or oppressive figures such as El Supremo and Cruz Chaparro in the past are now overpowered by a simple vulture's shadow. The statue too, an idol whose voice the Iatpeños would "hear", is demystified by the crime of the Goiburú brothers. It represents one of their own because the Itapeños had come to the conclusion that the statue of Christ is Gaspar's soul, not the symbol of Christ crucified. The statue is replaced by another of its kind; it is as ephemeral as its creator.

The darkness throughout the narration deepens in the last chapter, "The Aftermath”. It makes the somber and nearly invincible despair apparent in the crippled and mutilated veterans. To Isasi's death, as well as to the other deaths, the narrator Miguel Vera reacts with an equally pessimistic approach as one of Sartre's characters in No Exit. In it, the character Garcín, who is locked up with two women in an inescapable room, exclaims: "hell is—other people."26 The Son of Man's narrator likewise believes: "men cannot go on crucifying one another for ever. There must be an end to it. Otherwise one must come to the conclusion that the human race is for ever accursed, that hell is here and now and that there is no hope of salvation” (p. 262).

To counteract this mileu, the narrator, imbued with a sense of hope by his fellowmen who refuse to give up, states: "The strength of the fellow-feeling between them is their God. They may crush it, break it, shatter it, but the pieces join together again, and it is livelier and stronger than ever. And it moves in an ever widening spiral” (p. 256). Likewise, to the unbearable conditions that the Paraguayans have withstood throughout their history, to encourage and uplift his exploited, fellow countrymen, Roa Bastos opposes created myths, legends and supernatural stories: the fraternal feeling elevated to a God-like being; the myth of Casiano who escapes the tight surveillance in the plantation; the myth of the old man who appears ex nihilo to help Casiano, his wife and son; the legend of the train-car moving miles and miles, pushed by them; Gaspar's statue of the Christ, representing people; the story of the water truck miraculously pushed to its destination in the War of the Thirst. However, all of these are but myths, which last in time, not in eternity. The expression, "son of man," which is

${ }^{26}$ Jean Paul Sartre, No exit. New York: Vintage International, 1976, 45. 
used in the Gospels to refer to Jesus also identifies Him as the Son of God,

the high priest asked him and said to him, "Are you the Messiah, the son of the Blessed One?” Then Jesus answered, "I am; and 'you will see the Son of Man seated at the right hand of the Power and coming with the clouds of heaven."” (Mark: 14.62)

\section{Conclusion}

So, if the Son of Man is light, as per Jesus himself: "while I am in the world, I am the light of the world,"(Jn. 9.5) the misrepresentation of His mission, the cross, the Announciation, the halo of sanctity, and the spiritual rebirth translate into osbcurity in Roa Bastos' novel. Thus, the shadows, the circular structure that represents life as an insurmountable vicious circle in some of the above discussed episodes and other passages in the end. As when Crisanto, a soldier turned into a spoil of war, and his son, who leave behind a trail, is reminiscent of the dictator Rodríguez de Francia, "their shadows were gradually growing longer on the road behind them" (258). Hence, we get the death of Vera, the narrator, overshadowed by ambiguity and existencialist despair. In the eyes of his therapist, Dr. Rosa Monsón, the narrator, subconsciously wanted to punish himself for his aloofness and used Crisanto's son, Cuchuí (whom Vera had trained to use a gun), as his killer so that he would fire the gun whose trigger Vera lacked the courage to pull. Not surprisingly, when the symbols of eternal life have been deprived of their meaning, the trigger is easily pulled.

\section{References}

Audubert, R. (2002). El estigma de la cruz en Hijo de hombre de Augusto Roa Bastos. (The stigma of the cross in Son of Man by Augusto Roa Bastos). Revista de Estudios Literarios, 21.

Barthes, R. (2012). Mythologies. Myth today. (A. Lavers, Trans.). New York: Farrar, Straus and Giraux.

Berstein (2006, Aug. 17). Alfredo Stroessner; Paraguayan dictator. The Washington Post. Retrieved from http://www.washingtonpost.com

Breton, A. (1969). Manifestos of surrealism. (R. Seaver \& H. R. Lane, Trans.). Ann Arbor: U. Michigan.

Caffyn, R. (Trans.). (1988). Son of man. New York: Monthly Review Press.

Hann, S. G. (Ed.). (2009). Catholic Bible Dictionary. New York: Double Day, 2009.

Hebert, L. (2014). The actantial model. Signo: Theoretical Semiotics on the Web. All Things Have Become Signs in the Water's Reflection. Retrieved Aug., 13, 2014 from http://www.signosemio.com/greimas/actantial-model.asp

Kyeong Min, L. (2005). El poder de resistencia de la cultura popular dentro del Estado, en Hijo de hombre de Roa Bastos. (The power of popular cultural resistance within the state in Son of Man by Roa Bastos) Revista de Estudios Literarios (Espéculo). 29. Retrieved from http://www.ucm.es/info/especulo/numero/.html

Méndez-Faith, T. (1991). Dictadura y espacios cárceles: Doble reflejo de una misma realidad en Hijo de hombre y Yo el Supremo. (Dictatorship and Jail-like Spaces: Dual Reflection of the Same Reality in Son of Man and I, the Supreme). Cuadernos Hispanoamericanos: Revista Mensual de Cultura Hispánica.

Ó hÓgáin, D. (2008). Magic helper. In D. Haase (Ed.), The greenwood encyclopedia of folktales and fairy tales (Vols. 1-3). Connecticut: Greenwood Press.

Roa Bastos, A. (1961). Hijo de hombre (Son of Man) (2nd ed.). Buenos Aires: Editorial Losada.

Roa Bastos, A. M. (1986). An interview with Augusto Roa Bastos. In J. M. González (Ed.), Salmagundi 72 (pp. 22-20). (P. Boyers, Trans.).

Robles, H. (1974). El círculo y la cruz en Hijo de hombre. (The Circle and the Cross in Son of Man). Nueva Narrativa Hispanoamericana, 4, 193-219.

Robles, M. R. (1994). Syncretism in Roa Bastos’ Hijo de hombre. Romance Notes, 35(2), 194-197.

Sartre, J. P. (1989). No exit. New York: Random House.

Serra, M. V. (2006). Bilingüismo y dualidad en Hijo de hombre de Augusto Roa Bastos (Bilingualism and Duality in Son of Man by Augusto Roa Bastos). Espéculo: Revista de Estudios Literarios, 32.

Sombra. (2001). Diccionario de la lengua española (22nd ed.). 
St. Joseph (Ed.). (1992). New American Bible. New York: Catholic Book Publishing Co.

Stacy, R. H. (1974). Russian literary criticism: A short history. New York: Syracuse University Press.

Urte, L. (1976). Ensayo de interpretación de Hijo de hombre a través de su simbolismo cristiano y social. (Essay on the interpretation of Son of Man through its Christian and social symbolism). In H. F. Giacoman (Ed.), Homenaje a Augusto Roa Bastos: variaciones interpetativas en torno: variaciones interpetativas en torno a su obra (Homage to Augusto Roa Bastos: Interpretive variations revolving around his works) (pp. 169-185). New York: Las Américas. 